\title{
Human monocyte-derived dendritic cells exposed to hyperthermia show a distinct gene expression profile and selective upregulation of IGFBP6
}

\author{
Arcangelo Liso $^{1}$, Stefano Castellani ${ }^{1}$, Francesca Massenzio ${ }^{1}$, Rosa Trotta ${ }^{1}$, \\ Alessandra Pucciarini ${ }^{2}$, Barbara Bigerna ${ }^{2}$, Pasquale De Luca ${ }^{3}$, Pietro Zoppoli ${ }^{4}$, Filippo \\ Castiglione $^{5}$, Maria Concetta Palumbo ${ }^{5}$, Fabrizio Stracci ${ }^{6}$, Matteo Landriscina ${ }^{1,7}$, \\ Giorgina Specchia ${ }^{8}$, Leon A. Bach ${ }^{9,10}$, Massimo Conese ${ }^{1}$ and Brunangelo Falini ${ }^{2}$ \\ ${ }^{1}$ Department of Medical and Surgical Sciences, University of Foggia, Foggia, Italy \\ 2 Institute of Haematology, University of Perugia, Perugia, Italy \\ ${ }^{3}$ Stazione Zoologica A. Dohrn, Naples, Italy \\ ${ }^{4}$ Dipartimento di Medicina Sperimentale e Clinica, Università degli Studi Magna Graecia, Catanzaro, Italy \\ ${ }^{5}$ Institute for Applied Computing, National Research Council of Italy, Rome, Italy \\ ${ }^{6}$ Department of Experimental Medicine, Section of Public Health, University of Perugia, Perugia, Italy \\ ${ }^{7}$ Laboratory of Preclinical and Translational Research, IRCCS, Referral Cancer Center of Basilicata, Rionero in Vulture, Italy \\ ${ }^{8}$ Institute of Hematology, University of Bari, Bari, Italy \\ ${ }^{9}$ Department of Medicine, Alfred Hospital, Monash University, Melbourne, Australia \\ ${ }^{10}$ Department of Endocrinology and Diabetes, Alfred Hospital, Melbourne, Australia \\ Correspondence to: Arcangelo Liso, email: arcangelo.liso@unifg.it
}

Massimo Conese, email: massimo.conese@unifg.it

Keywords: apoptosis, B cells, chemotaxis, dendritic cells, hyperthermia, Immunology and Microbiology Section, Immune response, Immunity

Received: April 16, $2017 \quad$ Accepted: May 12, $2017 \quad$ Published: June 01, 2017

Copyright: Liso et al. This is an open-access article distributed under the terms of the Creative Commons Attribution License 3.0 (CC BY 3.0), which permits unrestricted use, distribution, and reproduction in any medium, provided the original author and source are credited.

\section{ABSTRACT}

Fever plays a role in activating innate immunity while its relevance in activating adaptive immunity is less clear. Even brief exposure to elevated temperatures significantly impacts on the immunostimulatory capacity of dendritic cells (DCs), but the consequences on immune response remain unclear. To address this issue, we analyzed the gene expression profiles of normal human monocyte-derived DCs from nine healthy adults subjected either to fever-like thermal conditions $\left(39^{\circ} \mathrm{C}\right)$ or to normal temperature $\left(37^{\circ} \mathrm{C}\right)$ for 180 minutes. Exposure of DCs to $39^{\circ} \mathrm{C}$ caused upregulation of $\mathbf{4 3}$ genes and downregulation of 24 genes. Functionally, the up/ downregulated genes are involved in post-translational modification, protein folding, cell death and survival, and cellular movement. Notably, when compared to monocytes, DCs differentially upregulated transcription of the secreted protein IGFBP-6, not previously known to be specifically linked to hyperthermia. Exposure of DCs to $39^{\circ} \mathrm{C}$ induced apoptosis/necrosis and resulted in accumulation of IGFBP-6 in the conditioned medium at $48 \mathrm{~h}$. IGFBP- 6 may have a functional role in the hyperthermic response as it induced chemotaxis of monocytes and $T$ lymphocytes, but not of $B$ lymphocytes. Thus, temperature regulates complex biological DC functions that most likely contribute to their ability to induce an efficient adaptive immune response.

\section{INTRODUCTION}

The effect of heat on cells can vary from survival and adaptation to apoptosis and, in extreme conditions, to necrosis [1-3]. These effects are either a direct consequence of heat itself on cellular components (e.g. denaturation of proteins) or a secondary effect mediated by cellular adaptive mechanisms such as the expression of 
heat shock proteins (HSPs) and the activation of selected signaling pathways. In turn, adaptive mechanisms are either related to changes in the activity of existing proteins (such as by phosphorylation/dephosphorylation or proteinprotein interactions) or to changes in protein expression. Whereas the heat shock response is an ancient and highly conserved essential process for surviving severe environmental stresses, fever is a more recently evolved physiological response [4]. Importantly, since fever is also a metabolically expensive process, its phylogenetic conservation from bony fish and amphibians to mammals highlights an important role in conferring a survival advantage. In fact, it is now clear that fever is beneficial in the infected host and this depends, at least in part, upon activation of the heat shock response [5]. Although the effects of moderate heat on cellular structure and function have been extensively studied in yeast, Drosophila melanogaster, and tissue culture cell lines [6-8], primary human cell populations have been more rarely investigated $[9,10]$. This is very relevant since the effects of heat can be cell-type specific, and a variety of temperature-mediated effects on immune cell function have been reported $[4,11,12]$.

Dendritic cells (DCs) are professional antigenpresenting cells [13-16], critical in modulating adaptive immune responses by sensing perturbations such as cell damage and inflammation in the microenvironment [1719]. Basu et al. [20] showed that even a brief exposure to elevated temperatures has a powerful effect on the immunostimulatory capacity of DCs. Furthermore, elevated temperatures cause immature DC to mature, specifically through elevation of intracellular levels of Hsp90. Moreover, DCs exposed to thermal stress showed enhanced expression of co-stimulatory molecules (CD80, CD83, CD86) and TNF- $\alpha$ and improved their ability to prime autologous naïve $\mathrm{CD}^{+} \mathrm{T}$ cells [21]. Monocytes, initially described as circulating precursors for tissue macrophages, were shown by Sallusto and Lanzavecchia [22,23] to differentiate into DCs. Over the last ten years, this observation has proven to be extremely useful for the study of human DC differentiation and maturation. Moreover, in vitro DC differentiation from monocytes constitutes the current methodological basis for obtaining DCs for their use in DC-mediated cancer immunotherapeutic treatments [24]. In recent years, monocyte-derived DCs (moDCs) have been generated for self-vaccination of otherwise incurable tumor patient [25].

Finally, understanding novel mechanisms regulating immune response in hyperthermia can be of pivotal importance in the clinical management of patients with fever. The aim of our study was to find novel and early players involved in the febrile immune response that could possibly be exploited for diagnostic and therapeutic purposes in the future.

With these premises in mind, we investigated whether exposure to $39^{\circ} \mathrm{C}$ induces a distinct gene expression profile program in moDCs and whether this allows identification of genes not previously known to be part of the response to hyperthermia. We found that human moDCs exposed to hyperthermia show a distinct gene expression profile including selective upregulation of IGFBP6. Importantly, we show that IGFBP-6 is able to induce chemotaxis of monocytes and T lymphocytes.

\section{RESULTS}

\section{DCs exposed to hyperthermia show a distinct gene expression profile}

Gene expression profile analysis was performed on samples obtained from nine consecutive donor patients. In all nine cases peripheral blood CD14 monocytes were easily obtained and differentiated to DCs, and maturation to the DC phenotype could be demonstrated (Supplementary Figure S1 in Supplementary Materials) at day six, resulting in a minimum of $11.6 \times 10^{6}$ cells ready for gene expression analysis. Incubation at $39^{\circ} \mathrm{C}$ for 3 and $24 \mathrm{~h}$ resulted in a significant increase of percentage of cells expressing maturation markers (CD11c, CD80, CD83, and HDRII), but not of CD14, if compared with cells incubated for the same duration at $37^{\circ} \mathrm{C}$ (Supplementary Figure S1 in Supplementary Materials).

A 3 h-exposure of DCs to $39^{\circ} \mathrm{C}$ caused a significant increase in the expression of 43 genes and a decrease of another 24 genes compared with $37^{\circ} \mathrm{C}$ (Table 1). A biologically meaningful effect was defined as significant when a greater than 2-fold difference in expression level was detected in all experiments. Genes that underwent up/downregulation under our stress conditions belong to several different functional categories including proteins involved in post-translational modification (e.g. $N U B 1$ and $C A C Y B P$ ), protein folding (e.g. CCT3), cell death and survival (e.g. $A N X A 1$ and KLF7), and cellular movement (e.g. IDO1) (Figure 1). Moreover, our study points to the important role of the heat shock response in the process of DC maturation upon fever-like conditions. Notably, multiple genes encoding for heat shock proteins (HSP90AB1, HSPA1A, HSPA1B, HSPA5, HSPA8, HSPB1, $H S P D 1, H S P E 1, H S P H 1)$ were all upregulated and this finding serves also as an internal control for the experiments. These data indicate the hyperthermia may increase the maturation of monocyte-derived DCs and show that a 3 h-exposure time to hyperthermia causes a modification in the global gene expression profile of DCs.

\section{DCs selectively upregulate IGFBP6}

Since we explored global gene expression profiling in order to search for early response genes involved in or governing the effects of hyperthermia on the immune 
system, it was intriguing that a few upregulated genes encoded secreted proteins, namely MANF, PLAT and $I G F B P 6$, which are potentially capable of interacting with other immune cells through receptors. Mesencephalic astrocyte-derived neurotrophic factor (MANF or ARMET) encodes for a secreted protein [26] localized in the endoplasmic reticulum (ER). Reduced expression of this gene has been linked to increased susceptibility to ER stress-induced death and cell proliferation [27]. Tissuetype plasminogen activator (PLAT) is a secreted serine protease, which converts the proenzyme plasminogen to plasmin [28]. This enzyme plays a role in cell migration and tissue remodeling. Finally, insulin-like growth factor binding protein-6 (IGFBP-6) was shown to inhibit the tumorigenic properties of IGF-II-dependent cancers [29]. Also, IGFBP-6 promotes migration of Rh30 rhabdomyosarcoma cells via a distinct pathway involving an unknown receptor [30,31].

We used quantitative RT-PCR to confirm upregulation of MANF, PLAT and IGFBP6 in DCs from four normal individuals who were unrelated to the previous cohort. Surprisingly, we found that although overall upregulation of the three genes was observed (Figure 2A), IGFBP6 was the only gene in which statistical significance could be demonstrated $(p=0.004)$, whereas PLAT $(p=0.089)$ and MANF $(p=0.05)$ did not reach statistical significance, probably due to variability in expression levels in a small cohort. These data show a selective up-regulation of IGFBP6 in monocyte-derived DCs exposed to hyperthermia for only $3 \mathrm{~h}$, suggesting $I G F B P 6$ as an early marker of fever-like temperature.

\section{IGFBP6 is upregulated in DCs but not in other cell types exposed to hyperthermia}

We then investigated whether hyperthermia-induced upregulation of the three genes (IGFBP6, PLAT, MANF) is a general biological phenomenon and whether any of those genes would be differentially regulated in DCs compared to other cell types exposed to $39^{\circ} \mathrm{C}$. Accordingly, we compared expression as measured by quantitative RTPCR in ontogenetically distant cell lines. In contrast to the $\sim 5$-fold increased IGFBP 6 expression in DCs, there was no significant increase after hyperthermia in human aortic endothelial cells (HAEC), human renal cells (HK2), or a number of human cancer cell lines (Figure 2B and 2C, Supplementary Figure S2 in Supplementary Materials) $[32,33]$. PLAT and MANF expression were also not significantly upregulated in the two cell lines (HAEC and HK2) in which they were studied (Figure 2B and 2C).

We also evaluated whether monocytes per se upregulate IGFBP6 expression in response to short exposure to hyperthermia, as they are directly related to DCs. We found that monocytes do not upregulate IGFBP6 $(p=0.9)$ (Figure 2D). These data show that upregulation of IGFBP 6 by hyperthermia occurs specifically in DCs and suggest that the ability to upregulate IGFBP6 is acquired at the dendritic stage, and therefore it might play a specific role in DC physiology. Given the consistency of IGFBP6 results, we then decided to focus our efforts on IGFBP6 in order to clarify whether it has additional properties and functions related to DC physiology.

A

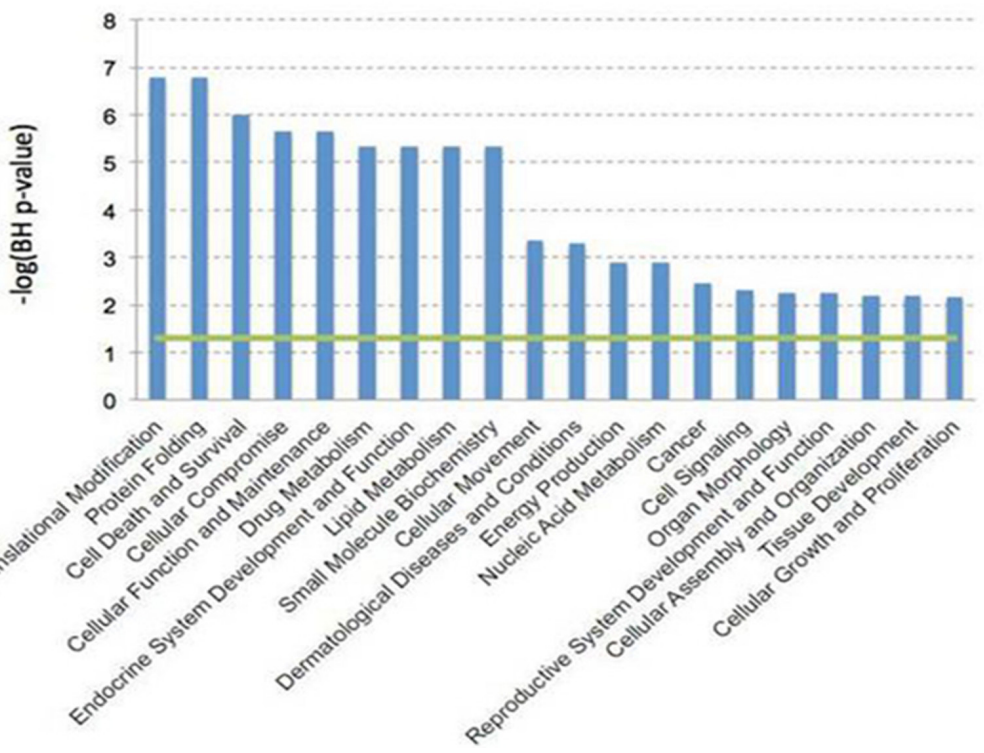

Figure 1: Gene expression profile data analysis. Dendritic cells expression profiles were evaluated by Affimetrix HGU133 Plus 2.0 array. Data were analyzed by Expression Console (Affymetrix Inc). All the biological functions values exceeding the threshold $(-\log (\mathrm{BH}$ $p$-value) $=1.3$ ), represented by the green line, identified by the IPA-Biofunction tool are statistically significant (i.e. the Benjamini-Hockberg FDR corrected $p$-value $<0.05$ ). 
Table 1: Differentially expressed up/downregulated genes.

\begin{tabular}{|c|c|c|}
\hline \multicolumn{3}{|c|}{ Downregulated } \\
\hline & Gene Symbol & Fold change \\
\hline 228603_at & ACTR3 & 2.1212146 \\
\hline 226025_at & ANKRD28 & 2.3790717 \\
\hline 233011_at & ANXA1 & 2.3608308 \\
\hline 225166_at & ARHGAP18 & 2.2429798 \\
\hline 235088_at & C4orf46 & 2.0362923 \\
\hline 229695_at & fam $107 b$ & 2.348431 \\
\hline 1554678_s_at & HNRPDL & 2.129529 \\
\hline 204334_at & KLF7 & 2.6032488 \\
\hline 230636_s_at & KLF9 & 2.1131873 \\
\hline 240655_at & LOC100133690 & 2.1164844 \\
\hline 244846_at & MAP4K4 & 2.2667267 \\
\hline 1558111_at & MBNL1 & 2.2078938 \\
\hline 1569030_s_at & NUB1 & 2.0441904 \\
\hline 214963_at & NUP160 & 2.017219 \\
\hline 225626_at & PAG1 & 2.0477161 \\
\hline 213933_at & PTGER3 & 2.5118344 \\
\hline 554999_at & RASGEF1B & 3.3729293 \\
\hline 226312_at & RICTOR & 2.2310023 \\
\hline 209684_at & RIN2 & 2.0676558 \\
\hline 220123_at & SLC35F5 & 2.102914 \\
\hline 215078_at & SOD2 & 2.2981791 \\
\hline 226837_at & SPRED1 & 2.4078321 \\
\hline 207983_s_at & STAG2 & 2.0910532 \\
\hline 217833_at & SYNCRIP & 2.120536 \\
\hline
\end{tabular}

\begin{tabular}{|c|c|c|c|c|c|}
\hline \multicolumn{6}{|c|}{ Upregulated } \\
\hline & Gene Symbol & Fold change & & Gene Symbol & Fold change \\
\hline 201491_at & AHSA1 & 3.0668783 & 201841_s_at & HSPB1 & 2.105686 \\
\hline 217911_s_at & BAG3 & 3.3147337 & 200806_s_at & HSPD1 & 3.5899048 \\
\hline 219966_x_at & BANP & 3.369214 & 200807_s_at & HSPD1 & 2.923671 \\
\hline $228928 \_x \_$at & BANP & 2.9106443 & 205133_s_at & HSPE1 & 3.3237238 \\
\hline 233186_s_at & BANP & 2.674547 & 235573_at & HSPH1 & 3.050632 \\
\hline 211761_s_at & CACYBP & 2.099444 & 208744_x_at & HSPH1 & 6.470141 \\
\hline 210691_s_at & CACYBP & 2.2031457 & 206976_s_at & HSPH1 & 8.415396 \\
\hline 206331_at & CALCRL & 2.0365825 & 200825_s_at & HYOU1 & 2.0537353 \\
\hline 210815_s_at & CALCRL & 2.2632575 & 210029_at & IDO1 & 2.4012868 \\
\hline 200910_at & CCT3 & 2.1207094 & 203851_at & IGFBP6 $^{a}$ & 2.2617126 \\
\hline 218566_s_at & CHORDC1 & 4.3639574 & 207901_at & IL12B & 2.0140626 \\
\hline 204170_s_at & CKS2 & 2.359756 & 227140_at & INHBA & 2.0002825 \\
\hline 225434_at & DEDD2 & 2.2326558 & 202220_at & KIAA0907 & 3.196178 \\
\hline 225061_at & DNAJA4 & 5.536901 & 1558404_at & LOC644242 & 2.2391515 \\
\hline 1554334_a_at & DNAJA4 & 4.3517003 & 218559_s_at & MAFB & 2.2515247 \\
\hline 1554333_at & DNAJA4 & 2.3606193 & 202655_at & MANF $^{\mathrm{a}}$ & 2.083146 \\
\hline 200664_s_at & DNAJB1 & 2.4289098 & 217907_at & MRPL18 & 2.3864717 \\
\hline 200666_s_at & DNAJB1 & 2.4802563 & 209785_s_at & PLA2G4C & 2.0645976 \\
\hline 209015_s_at & DNAJB6 & 3.323787 & 201860_s_at & PLAT $^{\mathrm{a}}$ & 2.0551631 \\
\hline 213145_at & FBXL14 & 3.1741052 & 204186_s_at & PPID & 2.0264704 \\
\hline 200894_s_at & FKBP4 & 2.268422 & 212706_at & RASA4 & 2.0581238 \\
\hline 200895_s_at & FKBP4 & 2.213333 & 203164_at & SLC33A1 & 2.208336 \\
\hline 222033_s_at & FLT1 & 2.0301073 & 212009_s_at & STIP1 & 2.211557 \\
\hline 201503_at & G3BP1 & 2.117231 & 213330_s_at & STIP1 & 3.3498967 \\
\hline 214359_s_at & HSP90AB1 & 2.6591988 & 223330_s_at & SUGT1 & 2.3122559 \\
\hline 200064_at & HSP90AB1 & 2.6207926 & 235542_at & TET3 & 2.130128 \\
\hline 1557910_at & HSP90AB1 & 3.1781142 & & & \\
\hline 200799_at & HSPA1A & 2.4917276 & & & \\
\hline 200800_s_at & HSPA1A /// & 4.0723443 & & & \\
\hline 202581_at & HSPA1A /// & 10.3153925 & & & \\
\hline 230031_at & HSPA5 & 2.2923908 & & & \\
\hline 211936_at & HSPA5 & 2.530812 & & & \\
\hline
\end{tabular}

${ }^{a}$ Genes also tested by RT-PCR are shown in bold. 


\section{IGFBP-6 protein expression in DCs exposed to hyperthermia}

Since upregulation of the IGFBP6 transcript was observed after a $3 \mathrm{~h}$ exposure to hyperthermia, we sought to investigate the time course of IGFBP- 6 protein expression starting at $3 \mathrm{~h}$. Flow cytometry with a specific monoclonal antibody revealed that DCs expressed detectable amounts of IGFBP-6 in comparison to samples stained with a control antibody both in permeabilized and non-permeabilized conditions (Supplementary Figure S3 and Supplementary Figure S4 in Supplementary Materials). Cell permeabilization was used to assess total protein expression. Cells were gated to exclude debris (Figure 3A), and the analysis was carried out on the gated populations. As shown in Figure 3C, $~ 80 \%$ of permeabilized cells expressed IGFBP-6 irrespective
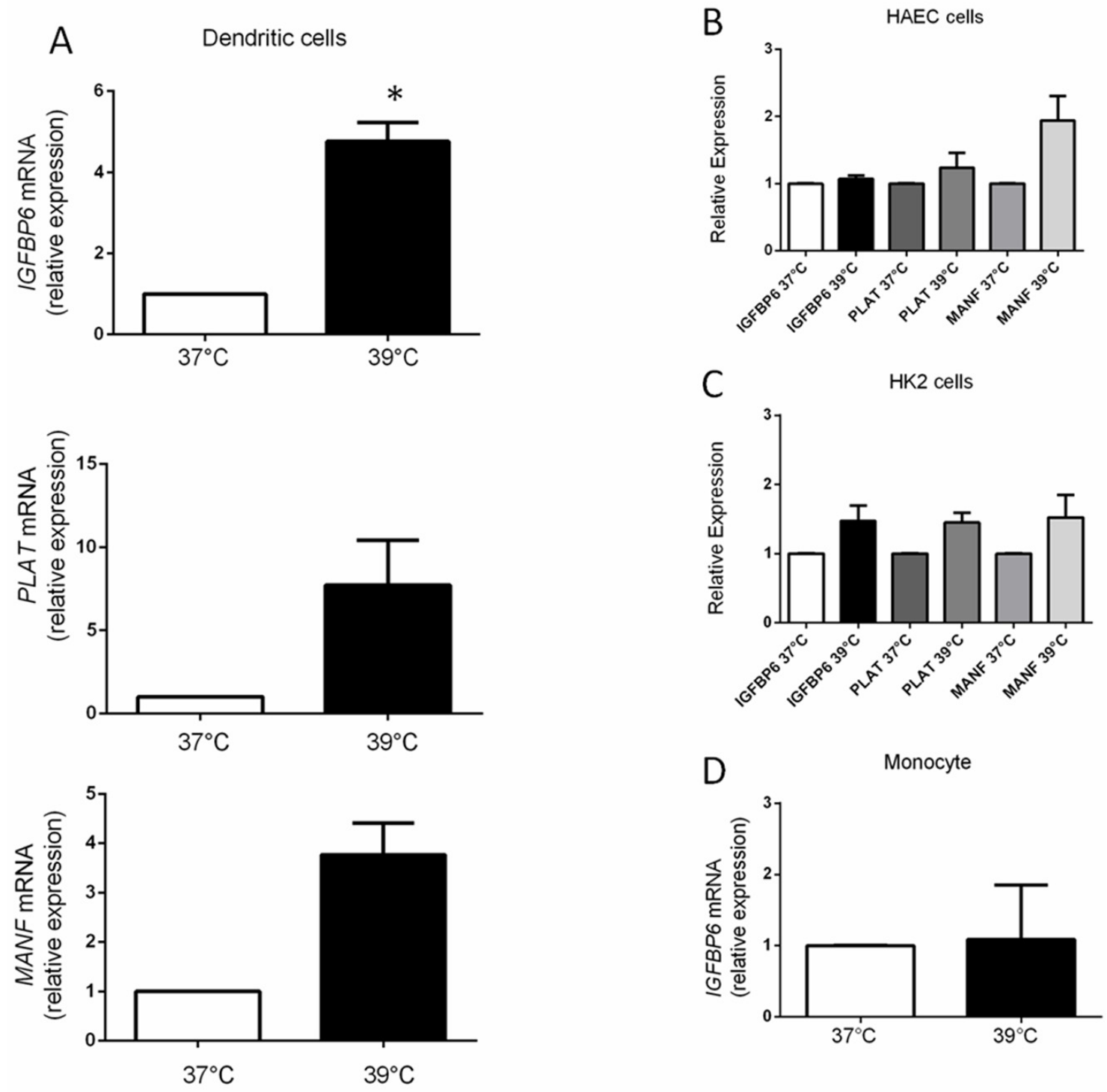

Figure 2: mRNA expression levels of $\boldsymbol{M A N F}, \boldsymbol{P L A T}$ and IGFBP6. A. MANF, $P L A T$ and $I G F B P 6$ expression by RT-PCR in DCs. mRNA levels were expressed relative to the GAPDH housekeeping gene by comparing PCR threshold cycle (CT) between cDNA of samples and $G A P D H(\triangle \mathrm{Ct})$. Relative expression was obtained by computing the $\Delta \Delta \mathrm{Ct}$ in comparison with the control sample $\left(37^{\circ} \mathrm{C}\right)$ which was set at 1 . Each bar represents mean \pm SEM of four independent experiments each performed in triplicate. Statistical comparisons were made using paired data Student's t-test. Differences were considered significant when $p<0.05$. IGFBP-6 was the only gene in which statistical significance could be demonstrated $(* p=0.004)$. B., C. Expression levels of MANF, PLAT and IGFBP6 by RT-PCR in HAEC and HK2 cells. In HAEC cells p-values for IGFBP6, MANF, PLAT were 0.26, 0.11, and 0.4 and in HK2 cells $0.16,0.25$, and 0.07 respectively. Each bar represents mean \pm SEM of three independent experiments each performed in triplicate. Statistical comparisons were made using paired data Student's t-test. D. Expression levels of IGFBP6 by RT-PCR in monocytes exposed to hyperthermia. Monocytes do not upregulate IGFBP-6 in response to hyperthermia. Each bar represents mean \pm SEM of three independent experiments each performed in triplicate. Statistical comparisons were made using paired data Student's $t$-test. 
of the temperature or exposure time. There was a significant decrease in the mean fluorescence intensity (MFI) of $39^{\circ} \mathrm{C}$-exposed DCs at 3 and $8 \mathrm{~h}$ (Figure 3D), and this pattern was reflected by imaging of positive cells (Supplementary Figure S5 in Supplementary Materials). No significant change was observed in the percentages of IGFBP-6 positive cells at all time points (Figure 3C), indicating that the overall population remained positive

A
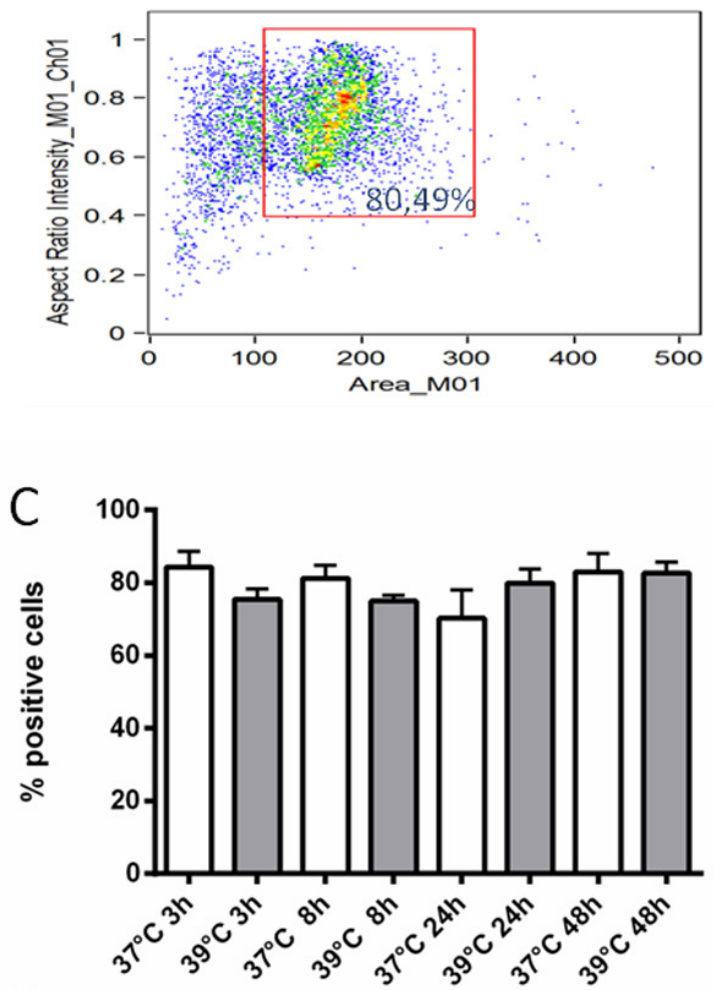

$E$

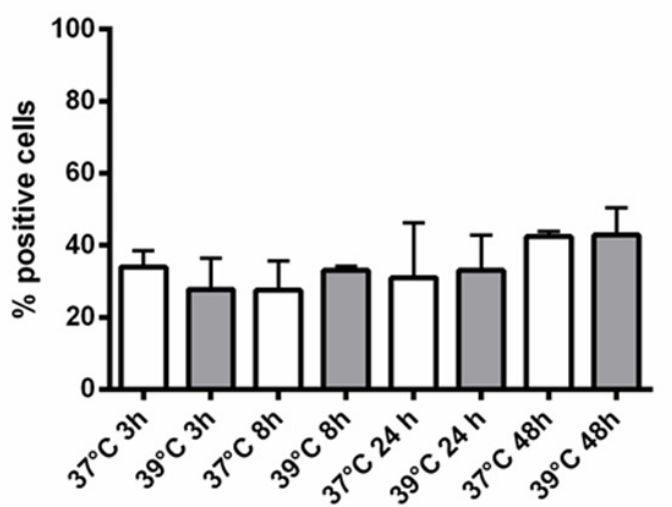

for IGFBP-6 while decreasing its intracellular pool of the protein. In order to see whether IGFBP-6 is expressed on the plasma membrane, the same experiment was carried out in the absence of permeabilization. This experimental condition did not alter cell viability (compare Figure $3 \mathrm{~B}$ with Figure $3 \mathrm{~A}$ ). The number of positive DCs was $\sim 50 \%$ lower than in the presence of permeabilization and did not change at $39^{\circ} \mathrm{C}$ (Figure 3E). Also, the MFI was

B
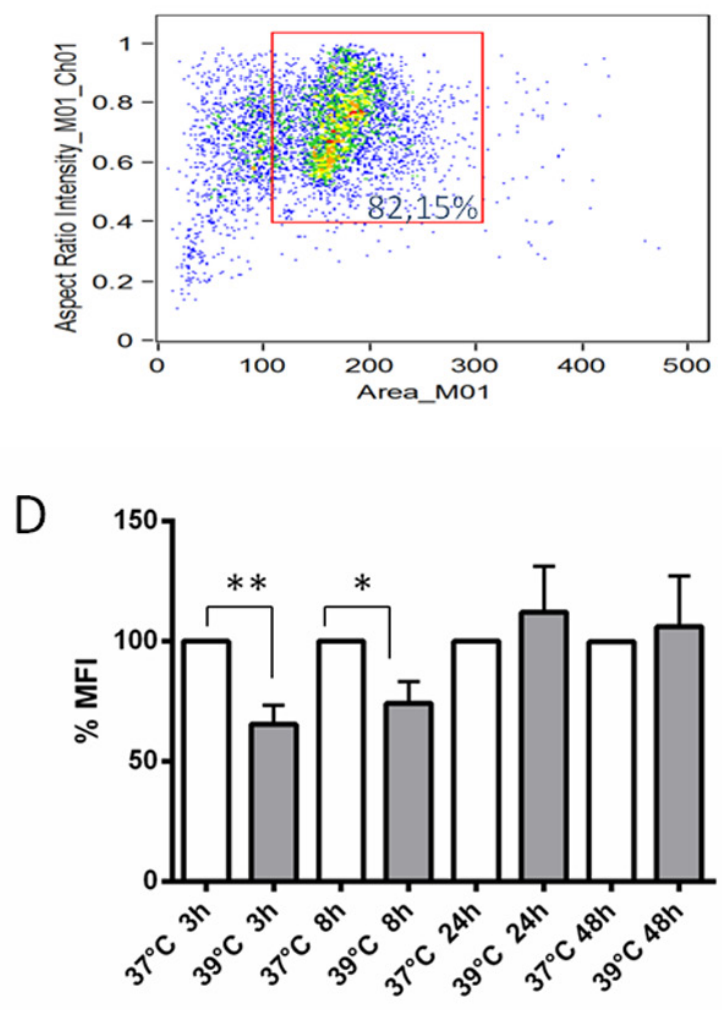

$\mathrm{F}$

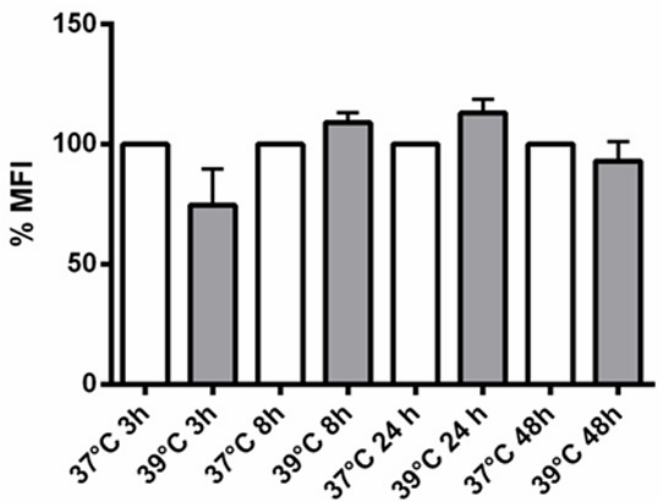

Figure 3: Expression levels of IGFBP-6 in DCs in presence or absence of permeabilization. A., B. The dot plots, obtained by plotting the area of the cells (x-axis) $v s$ the aspect ratio (i.e. the ratio between length and height) parameter (y-axis), displaying the typical distribution of DCs in presence (A) or in absence (B) of permeabilization, show that permeabilization did not alter cell viability. C., D., E., F. The percentage of cells expressing IGFBP- 6 after exposure at $39^{\circ} \mathrm{C}$ at different times and the relative percentage of mean fluorescence intensity (MFI) of cells exposed at $39^{\circ} \mathrm{C}$ towards cells exposed at $37^{\circ} \mathrm{C}$ (considered as $100 \%$ ) were analyzed by flow cytometry in the presence $(\mathrm{C}$ and $\mathrm{D}$, respectively) or absence of permeabilization ( $\mathrm{E}$ and F, respectively). No staining was seen with controls using either secondary antibody alone or isotype control rabbit IgG polyclonal antiserum (not shown). Each bar represents mean \pm SEM of four experiments. ${ }^{*} p<0.05 ;{ }^{*} p<0.001$. Statistical comparisons were made using unpaired Student's t-test. 
not significantly affected by exposure to $39^{\circ} \mathrm{C}$ (Figure $3 F)$. Individual cell imaging shows that IGFBP-6 was expressed on the plasma membrane and that the expression did not substantially change with temperature or time (Supplementary Figure S5 in Supplementary Materials). These data suggest that exposure to hyperthermia can decrease the pool of already synthesized IGFBP-6. We then hypothesized that IGFBP-6 was secreted upon exposure to $39^{\circ} \mathrm{C}$. Thus, we investigated whether IGFBP-6 was detectable in conditioned media by immunoassay after $3,8,24$ and $48 \mathrm{~h}$ of DC exposure to either $37^{\circ} \mathrm{C}$ or $39^{\circ} \mathrm{C}$. IGFBP- 6 concentrations were detectable only after $48 \mathrm{~h}$ of exposure at $39^{\circ} \mathrm{C}$ and found to be $0.635 \pm 0.023 \mathrm{ng} /$ $\mathrm{ml}(n=9)$, while the secreted protein was never detectable at $37^{\circ} \mathrm{C}$.

We then explored whether secretion was coupled to apoptosis and/or necrosis by incubating DCs for up to 48 h. As a positive control, DCs were incubated with $\mathrm{H}_{2} \mathrm{O}_{2}$ for $24 \mathrm{~h}$ (Table S1 in Supplementary Materials). As shown in Figure 4A, DCs displayed a different pattern of apoptosis and necrosis at $39^{\circ} \mathrm{C}$ compared to $37^{\circ} \mathrm{C}$. As judged by the lack of staining with both 7-AAD and Annexin V, DCs viability was around $85 \%$ at all time-points at both $37^{\circ} \mathrm{C}$ and $39^{\circ} \mathrm{C}$, with the notable exception of its decrease to $70 \%$ at $39^{\circ} \mathrm{C}$ for $48 \mathrm{~h}$ (Figure 4B). Concomitantly, late apoptosis and necrosis (AnxV-/7AAD+ and AnxV+/7AAD + ) were both abruptly increased at $48 \mathrm{~h}$, while early apoptosis (AnxV+/7AAD-) showed a more gradual increase at $39^{\circ} \mathrm{C}$ (Figure 4B). Overall, these data show that cell-associated IGFBP-6 protein expression decreases at early times upon exposure to hyperthermia and is followed by the appearance of IGFBP-6 in media coupled with apoptosis/necrosis of DCs at later times.

\section{IGFBP-6 promotes chemotaxis of monocytes and T lymphocytes}

Since we speculated that IGFBP-6 might have a novel role in immunity, based on its selective upregulation, we explored whether it could serve as a chemoattractant for monocytes and B and T lymphocytes using a Transwell migration assay. SDF-1, a known chemoattractant for these cell types [34-36], was used as a positive control. As shown in Figure 5A, supplementation of basolateral culture media with recombinant IGFBP-6 increased monocyte migration in a dose-dependent fashion to a maximum of $187 \pm 31 \%$ of control $(p<0.05)$. T cell chemotaxis was also significantly increased, showing a peak at $4 \mathrm{nM}(0.1 \mu \mathrm{g} / \mathrm{ml} ; 180 \pm 29 \%$ of control, $p<$ 0.05 ), with a behavior similar to SDF-1 (Figure 5B). Concentrations of IGFBP-6 lower than $4 \mathrm{nM}$ had no chemotactic activity for $\mathrm{T}$ cells (Figure 5B). Notably, IGFBP-6 did not exert a significant chemotactic effect on B lymphocytes (Figure 5C). Preincubation of IGFBP-6 with an anti-IGFBP-6 antibody abolished the chemotactic activity, while preincubation with an irrelevant antibody unexpectedly had a partial effect, as demonstrated by the statistically significant difference with the controls (Figure 5D). Moreover, we observed that an irrelevant mouse protein (Activin-A) produced with the same system used for IGFBP-6 and SDF-1 expression (insect cell culture infected with baculovirus) had no chemotactic effect at the equivalent concentration (Figure 5D, 5E, and 5F). These data strongly indicate that IGFBP-6 has a chemotactic effect on $\mathrm{T}$ cells and monocytes but not on B cells.

\section{DISCUSSION}

Fever is a fundamental host defense mechanism, which can occur in response to infectious agents, environmental stresses, medications and tumors. It is widely accepted that the physiological core body temperature is approximately $37^{\circ} \mathrm{C}$ and it is well conserved in vertebrates. Temperature is typically elevated to 38 $40^{\circ} \mathrm{C}$ in a febrile response to infection or other stresses. It is important to note that in vitro experimental temperatures used across immunological studies performed in the past are rather heterogeneous [37]. Obviously, thermal stress in the range of common febrile responses can be considered more clinically relevant and therefore we chose to perform our gene expression profiling studies at $39^{\circ} \mathrm{C}$.

It is becoming increasingly clear that different signals induce distinct programs of DC differentiation and different forms of immunity and tolerance [38]. In the past few years many advances have been made in addressing the action exerted by pathogen-associated molecular patterns (PAMPs), cytokines, chemokines, and other less characterized stress molecules on the activity of DCs. We analyzed the effects of temperature on gene expression programs in myeloid DCs generated in vitro from monocytes as a defined starting cell population. In fact, it has been clearly demonstrated that, in addition to functioning as macrophage precursors, monocytes have the capacity to differentiate into DCs, and therefore they play an essential role in both innate and adaptive immunity. In particular, both murine and human monocytes cultured with GM-CSF and IL-4 differentiate into immature DCs, characterized by their low expression of the costimulatory molecules CD80 and CD83 [39]. In keeping with our results (as shown in Supplementary Figure S1 in Supplementary Materials), these markers have been shown to be more highly expressed at $40^{\circ} \mathrm{C}$ [21]. Finally, CD11c has been found to be expressed at different levels in immature monocyte-derived DCs [40], and this is consistent with our data showing that about $50 \%$ of immature DCs are positive at $37^{\circ} \mathrm{C}$, increasing to about $66 \%$ after $24 \mathrm{~h}$ at $39^{\circ} \mathrm{C}$. Overall, we can conclude that mild thermal stress on DCs for $24 \mathrm{~h}$ at $39^{\circ} \mathrm{C}$ may enhance the function and immunostimulatory capacity of human DCs.

Obviously, in vitro monocyte differentiation systems 
A

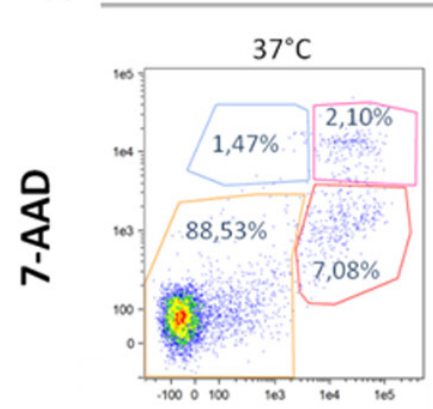

3h

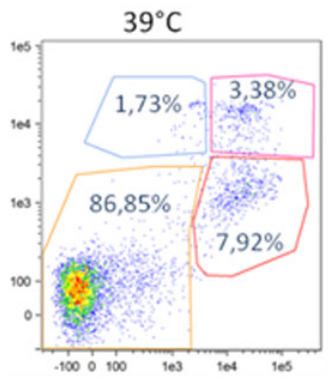

$8 \mathrm{~h}$

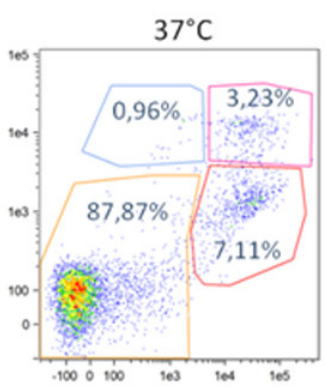

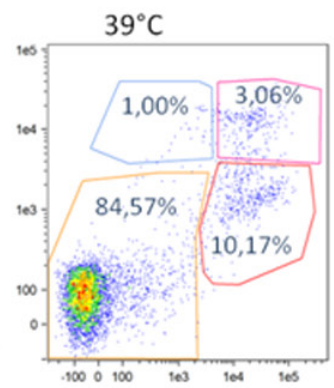

Annexin-V

$24 h$

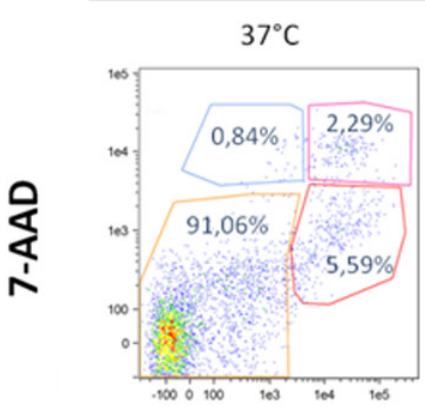

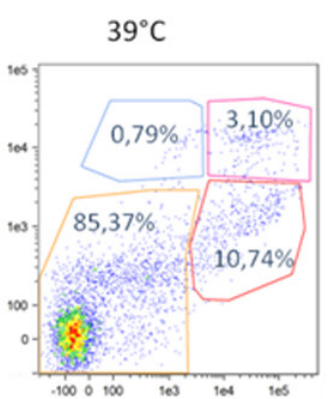

$48 \mathrm{~h}$

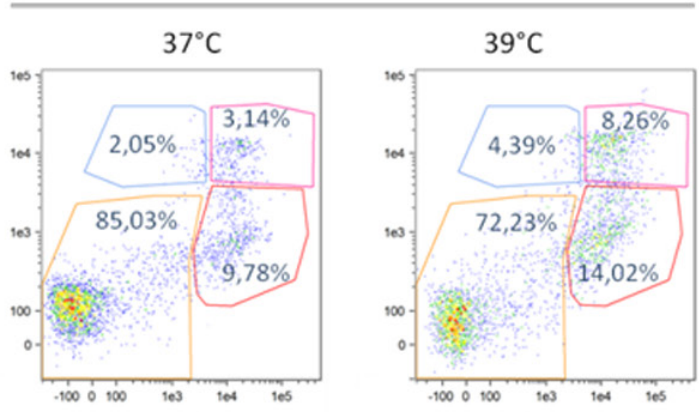

\section{Annexin-V}

B

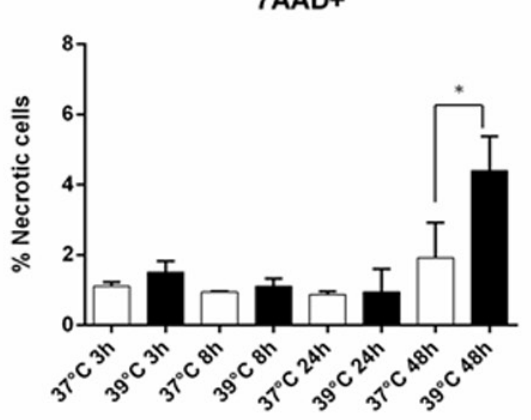

AnxV-7AAD-

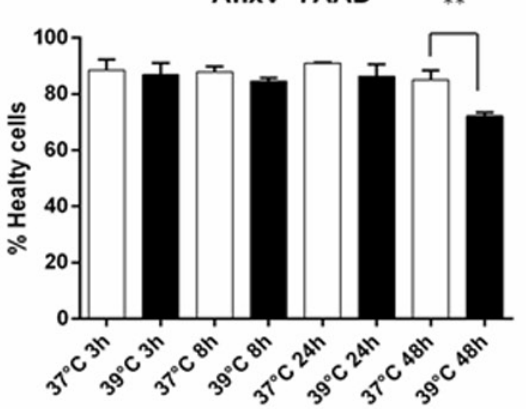

AnxV+ 7AAD+

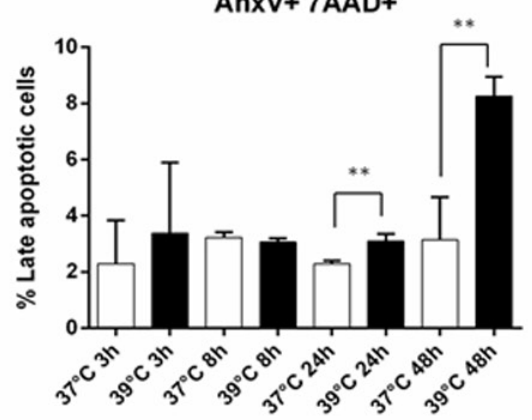

AnxV+

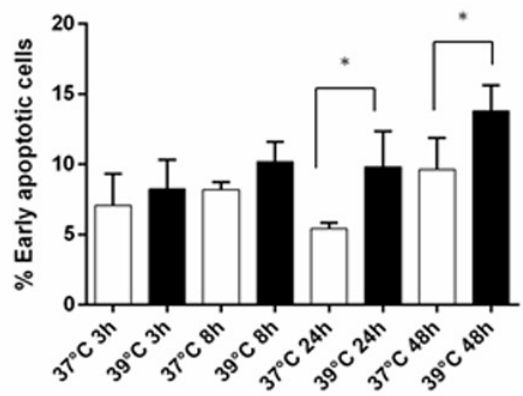

Figure 4: Apoptosis and necrosis induction by hyperthermia. DCs were analyzed for necrosis/apoptosis levels after exposure to hypertermic conditions for different time points. A. Representative AnnexinV versus 7-AAD dot plots of DCs after 3, 8, 24 and $48 \mathrm{~h}$ of exposure to normal and hyperthermic conditions are shown. B. The percentages of healthy (Annexin V- and 7-AAD-), necrotic (Annexin $\mathrm{V}+$ and 7-AAD+), early (Annexin $\mathrm{V}+$ and 7-AAD-) and late apoptotic (Annexin $\mathrm{V}-$ and 7-AAD+) cells are shown as mean $\pm \mathrm{SEM}$ of three independent experiments. ${ }^{*} p<0.05 ; * * p<0.001$. Statistical comparisons were made using paired data Student's t-test. 
cannot faithfully mimic all the physiological conditions that control in vivo monocyte differentiation. Furthermore, differentiation to DCs is generally observed in a fraction of the cultured monocytes, so this could also impair the detection of more subtle variation in gene expression. Nonetheless, these systems have proven to be a useful tool for studying factors that control DC differentiation, and, therefore, might provide information about the physiological situations in which this process takes place.

Four possible mechanisms have been proposed by which fever might confer protection [2-4]: i) directly killing or inhibiting growth of pathogens; ii) inducing cytoprotective HSPs in host cells; iii) inducing expression of pathogen HSPs, as activators of host defenses; iv) modifying and orchestrating host defenses. Our study highlights the central role of the heat shock response in the process of DC maturation upon feverlike conditions. Indeed, HSPs such as HSP60, HSP70 and HSP90 have been proposed to play a critical role in antigen presentation and DC activation [41] as part of their chaperone functions. It has been proposed that intracellular HSPs stimulate proteasome-dependent proteolysis and favor the generation of degradation products that are utilized as ligands of MHC class I molecules. This favors antigen recognition by $\mathrm{CD}^{+} \mathrm{T}$ cells, leading to activation of cytotoxic T cell immunity, which is indispensable in fighting viral infections [42]. In this context, HSP70 and HSP90 are involved in the crosspresentation of exogenous antigens by different antigenpresenting cells, including DCs and B cells. This is a direct consequence of their ability to act as chaperones and form complexes with peptides, which correlates with improved antigen delivery to endosomal compartments $[43,44]$. However, the putative role of HSPs in antigen cross-presentation has also been the subject of controversy [45]. Furthermore, several lines of evidence suggest that secreted extracellular HSP70 amplifies events associated with cytokine-dependent DC differentiation/maturation and may function to positively regulate the maturation of monocyte-derived DCs [46].

Since we explored global gene expression profiling in order to search for response genes besides HSPs involved in or governing the effects of hyperthermia on the immune system, it was intriguing that a few upregulated genes encoded secreted proteins, namely MANF, PLAT and IGFBP-6, which are potentially capable of interacting with other immune cells through receptors. Importantly, we showed that IGFBP6 transcription is consistently
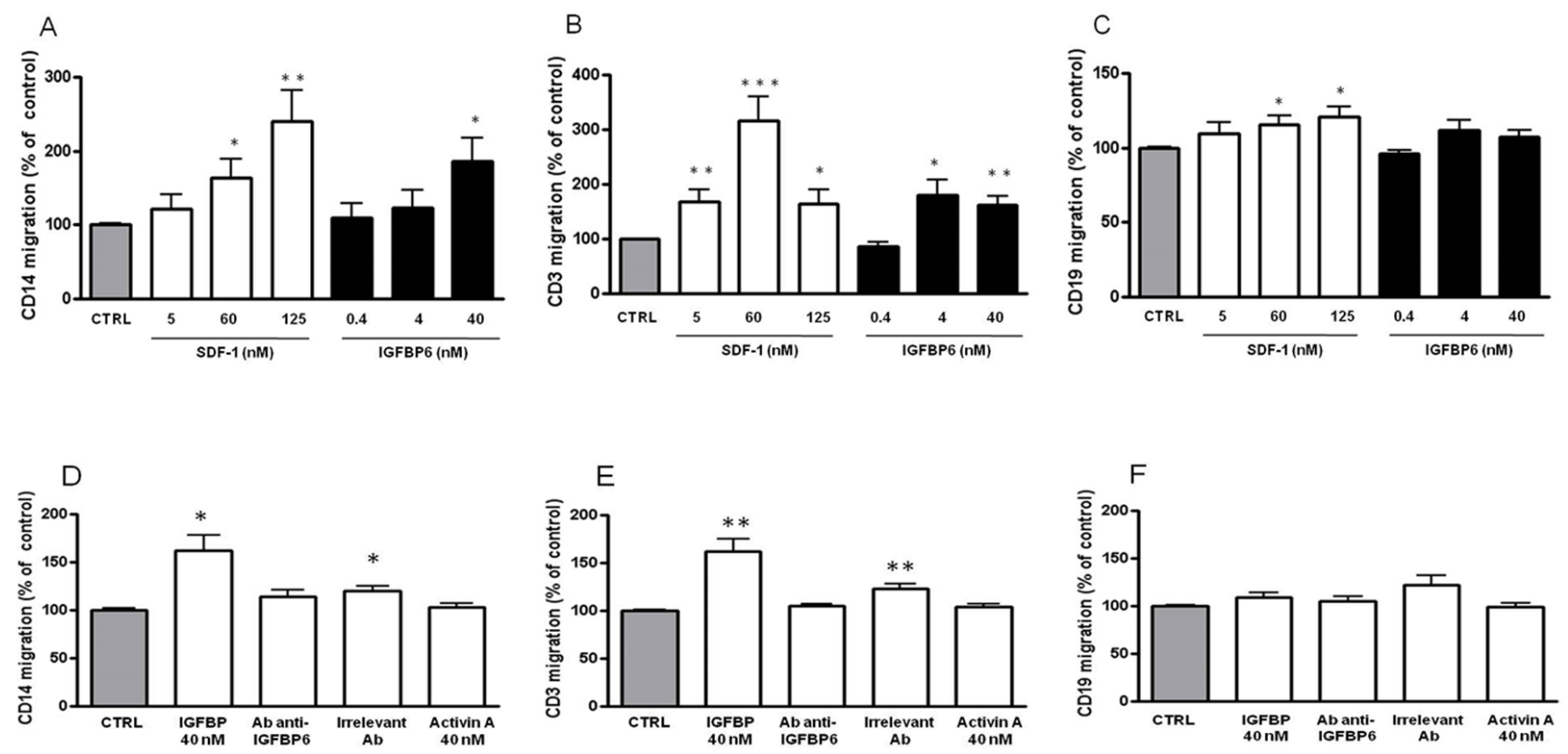

Figure 5: Chemoattractive effect of IGFBP-6 on monocytes, T lymphocytes and B lymphocytes. A., B., C. Monocytes (A), T lymphocytes (B) and B lymphocytes (C) were placed in the upper compartment of a Transwell in the absence or presence of IGFBP-6 at different concentrations in the lower compartment. Number of migrating cells across a $3 \mu \mathrm{m}$-pore membrane after 150 min was measured by flow cytometry. As a positive control, experiments were conducted in the presence of different concentrations of SDF-1 in the lower compartment. Results are shown as mean $\pm \mathrm{SEM}$ of three independent experiments and expressed as a percentage of controls obtained in the absence of IGFBP-6 in the basolateral compartment and set at $100 \%{ }^{*} p<0.05$; ${ }^{* *} p<0.001 ; * * p<0.0001$. D., E., F. In order to assess the specificity of the IGFBP-6 chemoattractive effect, monocytes (D), T lymphocytes (E) and B lymphocytes (F) were placed in the upper compartment of a Transwell in the presence in the lower compartment of: IGFBP-6 (40 nM); IGFBP-6 (40 nM) pre-incubated with an antibody directed against IGFBP-6; IGFBP-6 (40 nM) pre-incubated with an irrelevant antibody; Activin A (40 nM) as negative control. Results are shown as mean \pm SEM of three independent experiments and expressed as a percentage of control. ${ }^{*} p<0.05 ; * * p<0.001$. Results were analyzed using 2-way ANOVA with Tukey's Multiple Comparison test. 
and significantly upregulated by DCs as a response to hyperthermia. Also we show that IGFBP6 upregulation is specific for DCs, as this gene is not upregulated in epithelial cell lines (of endothelial and renal origin) or monocytes. Rather, upregulation of the gene appears to be a distinct feature that DCs acquire when maturing from monocytes.

While we found up-regulated IGFBP6 gene expression after $3 \mathrm{~h}$ of hyperthermia, we focused on the consequences of this increase at the protein level. Interestingly, intracellular staining did not reveal an increase in IGFBP-6 protein levels upon hyperthermia but rather a clear and significant decrease up to 8 hours with a later recovery (24-48 h), whereas membranebound staining was only slight decreased at $3 \mathrm{~h}$. These data indicate that IGFBP6 gene expression increase is not coupled with an increase in protein expression at earlier times and suggest that the decrease of intracellular IGFBP-6 could be recovered by subsequent synthesis. However, the decrease in cellular protein was not paralleled by the appearance of protein in the conditioned medium at earlier times, but rather required $48 \mathrm{~h}$ of hyperthermia. As many primary endogenous danger signals are released from the interior of the cell when the cell loses plasma membrane integrity upon necrosis [47], it is conceivable that necrotic DCs may also release signals able to activate adaptive immune cells. Therefore, we studied whether secretion of IGFBP-6 was linked to necrosis, finding actually that this was the case.

Notably, IGFBP-6 protein is well known to inhibit the actions of IGF-II including proliferation, differentiation, migration and survival in many cell lines [29]. However, more recent studies also suggest novel actions independent of IGF. In particular, IGFBP-6 (40 $\mathrm{nM}, 1 \mu \mathrm{g} / \mathrm{ml}$ ) has been shown to induce chemotaxis in Rh30 rhabdomyosarcoma cells [30]. Therefore, we investigated whether IGFBP-6 possesses any chemotactic capability in regard to freshly isolated peripheral monocytes and lymphocytes. Importantly, we showed that IGFBP-6 induced chemotaxis of monocytes and $\mathrm{T}$ lymphocytes, but not of B lymphocytes. Interestingly, the chemotactic effect of IGFBP-6 was only seen at $\sim 150$-fold higher concentrations than those found in the conditioned medium. Notwithstanding the problems with extrapolating in vitro findings to the in vivo situation, this suggests that there may be a threshold of DC activation resulting in sufficient secretion of IGFBP-6 for it to mediate chemotaxis. Nevertheless, it can be speculated that secretion of the signal (IGFBP-6) from DCs during hyperthermia may ultimately favor DC-T cells encounters. However, currently we do not know if different DC subtypes (e.g. activated DCs) act differently in terms of their capacity to secrete IGFBP-6, nor if different T cell subsets in vivo would act differently when exposed to IGFBP-6. In fact, our results warrant further studies to shed light on what happens in vivo, with particular emphasis on lymphoid organs where $\mathrm{T}$ cells meet antigen and initiate an adaptive immune response. Given that IGFBP-6 has recently been associated with several pathological conditions [48-50], further studies are warranted in order to evaluate how IGFBP-6 is governing chemotaxis and whether this protein might also play a pathogenetic role in autoimmunity.

\section{MATERIALS AND METHODS}

\section{Ethics statement}

Specific approval of the local ethics committee was obtained for this study (Ospedali Riuniti University Hospital cod. 30/CE/2014). Written informed consent was obtained from all participants.

\section{Monocyte-derived dendritic cells isolation}

Nine consecutive healthy adult blood donors were recruited without regard to age, ethnic origin, or gender. DCs were generated starting from selected CD14-positive cells obtained using Miltenyi MicroBeads (Miltenyi Biotec, Bergisch Gladbach, Germany). Briefly, after density gradient centrifugation, positively selected cells were plated in flasks or $75 \mathrm{~cm}^{2}$ roller bottles, at a density of $100 \times 10^{6}$ cells in $10 \mathrm{ml}$ of complete culture medium AIM-V (Invitrogen, Frederick, MD, USA) and incubated at $37^{\circ} \mathrm{C}$ and $5 \% \mathrm{CO}_{2}$ adding GM-CSF (50 ng/ $\mathrm{ml}$ ) (Schering-Plough, Milan, Italy) and IL-4 (1000 U/ ml) (Peprotech, London, UK). DCs were cultured for 6 days [23]. Finally, in order to confirm the expected DC phenotype, cells were stained with specific mAbs or appropriate isotype controls for 30 minutes at $4^{\circ} \mathrm{C}$ in FACS buffer Dulbecco's PBS (Lonza, Basel, Switzerland) containing 2\% FBS (PAA GmbH, Pashing, Austria), washed twice and finally resuspended in cold FACS buffer containing $0.1 \mu \mathrm{g} / \mathrm{mL}$ propidium iodide (PI) (Carl Roth, Karlsruhe, Germany). Stained cells were immediately analyzed with Epics XL-MCL ${ }^{\mathrm{TM}}$ flow cytometer (Beckman Coulter, Brea, CA, USA). Cell debris and dead cells were excluded from the analysis by gating on proper forward and sideward light scatter and on PI negative cells $(\sim 98 \%)$. A minimum of $1 \times 10^{4}$ living cells derived from a single flask per condition were analyzed for each sample and results were analyzed using Expo 32 ADC Software (Beckman-Coulter). The following monoclonal antibodies were used to determine the phenotype of DCs: antiCD14; anti-CD80; anti-CD11c; anti-CD83; anti-HDRII (Beckman-Coulter). Some flasks were then moved to $39^{\circ} \mathrm{C}$ for $3 \mathrm{~h}$ or $24 \mathrm{~h}$. In all cases, parallel control cultures were handled by culturing cells at $37^{\circ} \mathrm{C}$. 


\section{Gene expression profiles: sample preparation and hybridization}

Cells were lysed in TRIZOL (Invitrogen, Frederick, $\mathrm{MD}$, USA) and total RNA was further purified with the QIAGEN RNeasy kit following manufacturer's instructions. RNA was quantified on the NanoDrop ND1000 and quality checked with the 2100 Bioanalyzer (Agilent Technologies, Santa Clara, CA, USA). Five $\mu \mathrm{g}$ of total RNA were retrotranscribed from a T7-oligo(dT) primer with the SuperScript II polymerase (Invitrogen). cDNA was then purified on affinity columns and in vitro transcribed with the T7 RNA polymerase and a biotinylated dUTP. Labeled cRNA was purified on affinity columns and quantified on the NanoDrop ND-1000. Twenty $\mu \mathrm{g}$ of cRNA were fragmented and quality checked with the 2100 Bioanalyzer (Agilent Technologies). The biotinylated cRNA was hybridized to the Affimetrix HGU133 Plus 2.0 array, containing about 55,000 probe sets and open reading frames from the $H$. sapiens genome databases GenBank, dbEST and RefSeq. Chips were washed and scanned on the Affymetrix Complete GeneChip ${ }^{\circledR}$ Instrument System, generating digitized image data (DAT) files.

\section{Microarray data analysis}

DAT files were analyzed by Expression Console (Affymetrix Inc.). We used the Robust Multi alignment Algorithm [51] to normalize the full data set. The expression values obtained were analyzed by using GeneSpring GX 10 (Agilent Technologies). Further normalization steps included per-chip normalization to $50^{\text {th }}$ percentile and per-gene normalization to median. Normalized data were filtered for fold changes greater than 2, giving a list of 67 genes on 83 probe sets. We will refer to this set of differentially expressed genes as "focus gene list". The fold change is defined as the ratio between the averages of the normalized expression values at temperatures of $39^{\circ} \mathrm{C}$ and at $37^{\circ} \mathrm{C}$. Microarray data are available in the ArrayExpress database (www.ebi.ac.uk/ arrayexpress) under accession number E-MTAB-697.

\section{Analysis of gene expression data}

The analysis algorithm from Ingenuity Pathway Analysis (IPA; Ingenuity ${ }^{\circledR}$ Systems, www.ingenuity. com) was used to identify the biological functions (IPA's biofunction tool) and knowledge-based networks (IPA's network generation tool) from the differentially expressed focus genes. The analysis points out the biological functions and/or diseases that were most significantly associated with the considered data sets, in particular leveraging information on the biological interactions stored in the Ingenuity Pathway Knowledge Base (IPKB). Focus genes were associated with biological functions and/or diseases in the IPKB. Fisher's exact test [52] was used to calculate the probability (p-value) that each biological function/disease association is due to chance alone. Furthermore, resulting p-values were corrected for multiple testing using the Benjamini-Hockberg False Discovery Rate (FDR) [53].

\section{Cell lines}

Human HK2 renal tubular cells were cultured in 50\% DMEM and 50\% HAM's F12 supplemented with $10 \%$ fetal bovine serum, $2 \mathrm{mM}$ L-glutamine, $100 \mathrm{IU} / \mathrm{ml}$ penicillin and $100 \mu \mathrm{g} / \mathrm{ml}$ streptomycin (Invitrogen). Human aortic endothelial cells (HAEC) were cultured in $\mathrm{EBM}^{\mathrm{TM}}-2$ (endothelial basal Medium-2), supplemented with $\mathrm{EGM}^{\mathrm{TM}}-2$ BulletKit ${ }^{\mathrm{TM}}$ (EBM ${ }^{\mathrm{TM}}-2$ plus SingleQuots ${ }^{\mathrm{TM}}$ of growth supplements) containing BBE (Bovine Brain Extract), hEGF, hydrocortisone, GA1000 (Gentamicin, Amphotericin-B), FBS (Fetal Bovine Serum),VEGF, hFGF-B, R3-IGF-1, ascorbic acid, heparin (Lonza). Human colon cancer cell line (HCT116), human breast adenocarcinoma cell line (MCF-7 Cells), human prostate cancer cell line (PC3), heterogeneous human epithelial colorectal adenocarcinoma cell line (CACO2) were cultured in Dulbecco's modified Eagle's medium (DMEM) supplemented with $10 \%$ fetal bovine serum (FBS) , 1\% PenStrep (10,000 U/mL Pen, $10 \mathrm{mg} / \mathrm{mL}$ Strep) $2 \mathrm{mM}$ L-glutamine (medium and reagents from SigmaAldrich, Milan, Italy).

\section{Real Time RT-PCR analysis}

For each sample, total RNA was isolated using TRIZOL (Invitrogen). RNA was quantified on NanoDrop ND-1000 and quality checked with the 2100 Bioanalyzer using the average A260/280 ratio of 2.0. For the first strand synthesis of cDNA, three $\mu \mathrm{g}$ of RNA were used in a $20 \mu \mathrm{l}$ reaction mixture using Oligo (dT) primers and cDNA Superscript II (Invitrogen) according to the supplier's instructions. For real-time PCR, the following primers were used: IGFBP6, forward 5'-GGAAGCTGAGGGCTGTCTC-3', reverse 5'-GTCTCTGCGGTTCACATCCT-3'; ARMET forward 5'-CTGAGCACAGTGGACCT-3', reverse 5'-GGCTGTTTTGGGAGTAA-3'; PLAT forward 5'-AGGGCTGGAGAGAAAAC-3', reverse 5'-CTGGCTCCTCTTCTGAAT-3'; GAPDH forward 5'-CAAGGCTGAGAACGGGAA-3', reverse 5'-GCATCGCCCCACTTGATTTT-3'. Primers were designed to be intron spanning.

The size of the products was also confirmed by gel electrophoresis for selected samples. mRNA levels were expressed relative to the housekeeping gene by 
comparing PCR threshold cycle (CT) between cDNA of samples and GAPDH $(\triangle \mathrm{CT})$. Relative gene expression subsequently was calculated as follows: fold change $=$ $2^{-\Delta(\triangle C T)}$, where $\Delta C T=C$ Ttarget - CThousekeeping and $\Delta(\Delta C T)=\Delta C$ Ttreated $-\Delta C$ Tcontrol. All experiments were performed in triplicate per sample. The Student's t-test for paired data was used to assess gene expression at different temperatures for the three selected genes. All tests were two-sided and significance was set at $p<0.05$.

\section{Flow cytometry}

After incubation for 3, 8, 24 and $48 \mathrm{~h}$ at $39^{\circ} \mathrm{C}$ (or $37^{\circ} \mathrm{C}$ as control), cells were fixed in $3 \%$ paraformaldehyde and $2 \%$ sucrose in PBS and permeabilized (or not) with ice-cold Triton HEPES buffer (20 mM HEPES, 300 $\mathrm{mM}$ sucrose, $50 \mathrm{mM} \mathrm{NaCl}, 3 \mathrm{mM} \mathrm{MgCl}_{2}, 0.5 \%$ Triton $\mathrm{X}-100, \mathrm{pH} 7.4$ ) for $5 \mathrm{~min}$ at room temperature. Then, cells were incubated with rabbit anti-human IGFBP-6 (Abcam; ab135606) for $1 \mathrm{~h}$ at $4^{\circ} \mathrm{C}$ (dilution 1:25), washed twice with $\mathrm{PBS}$, and incubated with secondary antibody donkey anti-rabbit IgG (Alexafluor 488) for 30 minutes at $4{ }^{\circ} \mathrm{C}$ (dilution 1:1000). As a negative control, cells were incubated either only with secondary antibody or with a rabbit $\mathrm{IgG}$, polyclonal - isotype control (Abcam; ab37415) followed by incubation with secondary antibody. To evaluate the number of dead cells after fixation, Zombie Aqua Fixable Viability kit (BioLegend, San Diego, USA) was used. Then cells were washed twice with PBS, resuspended in $50 \mathrm{ml}$ PBS and then analyzed by AmnisFlowsight IS100 (Merck Millipore). Brightfield scatter plots obtained by plotting Area (a parameter relative to cellular dimension) on $\mathrm{x}$-axis vs Aspect Ratio (a parameter reflecting the ratio of the cell Minor Axis divided by the Major Axis) on $y$-axis were generated, then single cells events were gated, and finally 20,000 singlecell events for sample were acquired. The percentage of green positive cells (channel 2, $488 \mathrm{~nm}$ excitation laser) and mean fluorescence were analyzed using Amnis IDEAS software subtracting the values of the negative control. Brightfield and green fluorescent images for any single cell event were collected. A representative image of a single cell for any condition is shown. Zombie Dye staining revealed that an average of $4 \%$ of unfixed cells and $10 \%$ of fixed cells were dead.

\section{Analysis of secreted IGFBP-6 in conditioned medium}

After 3, 8, 24 and 48 h exposure of DCs to either $37^{\circ} \mathrm{C}$ or $39^{\circ} \mathrm{C}$, conditioned media were harvested and centrifuged at $200 \mathrm{x} \mathrm{g}$ at $4^{\circ} \mathrm{C}$ for $12 \mathrm{~min}$ and proteinase inhibitor (Aprotinin, Boehringer Mannheim $\mathrm{GmbH}$ ) was added. Secreted protein in each sample was detected using a Bio-Plex cytokine, chemokine and growth factor assay
(Bioclarma, Turin, Italy) according to manufacturer's protocol. Briefly, the assay for IGFBP-6 was carried out in 96-well microplates using the Human IGF Binding Protein (IGFBP-6) Magnetic Bead Panel (HIGFBMAG-53K, Millipore) at the Bioclarma - Research and Molecular Diagnostics, Torino, Italy. Undiluted supernatant samples were treated according to manufacturer's instructions and the contents of each well were drawn up into the BioPlex 100 System array reader (Bio-Rad), which identifies and quantifies each specific reaction based on bead color and fluorescent signal intensity. The data were finally processed using Bio-Plex Manager software (version 6.1) using five-parametric curve fitting and converted to $\mathrm{ng} / \mathrm{mL}$. The concentration of samples was obtained by comparing the fluorescence to that obtained from a standard curve. The sensitivity limit of the assay is 0.04 $\mathrm{ng} / \mathrm{mL}$.

\section{Apoptosis and necrosis}

DCs were incubated for $3,8,24$ and $48 \mathrm{~h}$ at $39^{\circ} \mathrm{C}$ (or maintained at $37^{\circ} \mathrm{C}$ as control) and evaluated for apoptosis/necrosis rate by using the FlowCellect ${ }^{\mathrm{TM}}$ Annexin Red Kit (Merck Millipore), according to the manufacturer's instructions. Briefly cells were stained with Annexin V conjugated with a sensitive dye CF647 (excitation laser: $642 \mathrm{~nm}$, emission max: $670 \mathrm{~nm}$ ) for 15 min at $37^{\circ} \mathrm{C}$, washed in assay buffer, then stained with 7-AAD (excitation laser: $488 \mathrm{~nm}$, emission max: $642 \mathrm{~nm}$ ) for $5 \mathrm{~min}$ and analyzed by AmnisFlowsight IS100 (Merck Millipore). Brightfield aspect ratio versus brightfield area plots were generated to identify single cells events, then 20,000 single-cell events for sample were acquired. Dot plots were obtained by plotting the fluorescence of AnnexinV (channel 11) versus fluorescence of 7-AAD (channel 5), resulting in four different populations: (1) healthy cells, Annexin V(-) and 7-AAD(-); (2) necrotic cells, Annexin $\mathrm{V}(+)$ and 7-AAD $(+)$; (3) early apoptotic cells, Annexin $\mathrm{V}(+)$ and 7-AAD(-); (4) late apoptotic cells, Annexin $\mathrm{V}(-)$ and 7-AAD $(+)$.

\section{Cell chemotaxis}

Human PBMC were isolated from buffy coats of healthy donors and used to purify $\mathrm{CD}^{+} 4^{+}$monocytes, CD $19^{+} \mathrm{B}$ cells and, $\mathrm{CD}^{+} \mathrm{T}$ cells with magnetic microbeads kit (Miltenyi Biotec). In order to evaluate chemotactic activity of IGFBP-6, monocytes, T and B lymphocytes were added $\left(10^{6}\right.$ per filter $)$ to the upper compartment of $0.33 \mathrm{~cm}^{2}$ Transwells with $3 \mu \mathrm{m}$-pore filters (Corning, Acton, MA, USA), while no IGFBP-6 (as control) or different concentrations of IGFBP-6 (Peprotech, London, UK) $(0.01 \mu \mathrm{g} / \mathrm{ml}, 0.1 \mu \mathrm{g} / \mathrm{ml}, 1 \mu \mathrm{g} / \mathrm{ml})$ corresponding respectively to $0.4,4$, and $40 \mathrm{nM}$ were dissolved in serum free Eagle's Medium minimal essential medium (MEM; 
Sigma-Aldrich, Milan, Italy) in the lower compartment. As a positive control, different concentrations of SDF1 (Peprotech, London, UK) $(0.05 \mu \mathrm{g} / \mathrm{ml}, 0.5 \mu \mathrm{g} / \mathrm{ml}, 1$ $\mu \mathrm{g} / \mathrm{ml}$ ) corresponding respectively to $6 \mathrm{nM}, 60 \mathrm{nM}$ and $125 \mathrm{nM}$ were added to the lower compartment. In order to assess for the specificity of the IGFBP- 6 chemotactic effect, we pre-incubated IGFBP-6 at the highest dose with a rabbit IgG anti-human C-terminal IGFBP-6 antibody (Abcam, Cambridge, UK) or with an irrelevant rabbit IgG antibody (anti-human HVCN1, Abcam, Cambridge, UK) in a weight ratio (IGFBP-6/antibody) of 1:6 for $30 \mathrm{~min}$ at room temperature, before adding the mixture in the lower compartment. Moreover, as a negative control, we used recombinant human/murine/rat (insect-derived) Activin A (Peprotech, London, UK), in the lower compartment at a dose of $40 \mathrm{nM}$. After $150 \mathrm{~min}$, cells were recovered in the lower compartment and quantified by flow cytometry, and data were expressed as percentage of migration of the control $(100 \%)$. The concentrations used for SDF-1 were previously shown to be optimal for chemotaxis of monocytes, T and B lymphocytes [29-31].

\section{Statistical methods}

Data obtained from apoptosis/necrosis and chemotaxis experiments are shown as mean \pm standard error of the mean (SEM) and analyzed for statistical significance using 2-way ANOVA with Tukey's Multiple Comparison test using Graphpad Software v. 4 (La Jolla, CA, USA). $p<0.05$ was considered statistically significant.

\section{ACKNOWLEDGMENTS}

We are grateful to Michele Centra (Ospedali Riuniti di Foggia) for advice. S. Castellani is a researcher funded by Intervento Cofinanziato dal Fondo di Sviluppo e Coesione 2007-2013 - APQ Ricerca Regione Puglia "Programma regionale a sostegno della specializzazione intelligente e delle sostenibilità sociale ed ambientali Future In Research".

\section{CONFLICTS OF INTEREST}

All authors declare that the research was conducted in the absence of any commercial or financial relationships that could be construed as a potential conflict of interest.

\section{FUNDING}

We thank Associazione Italiana contro le LeucemieLinfomi e Mieloma (Section of Foggia) for funding (A. Liso).

\section{Editorial note}

This paper has been accepted based in part on peerreview conducted by another journal and the authors' response and revisions as well as expedited peer-review in Oncotarget.

\section{REFERENCES}

1. Creagh EM, Sheehan D, Cotter TG. Heat shock proteinsmodulators of apoptosis in tumour cells. Leukemia. 2000; 14:1161-1173.

2. Jaattela M. Heat shock proteins as cellular lifeguards. Ann Med. 1999; 31:261-271.

3. Punyiczki M, Fesus L. Heat shock and apoptosis. The two defense systems of the organism may have overlapping molecular elements. Ann N Y Acad Sci. 1998; 851:67-74.

4. Hasday JD, Singh IS. Fever and the heat shock response: distinct, partially overlapping processes. Cell Stress Chaperones. 2000; 5:471-480.

5. Hobohm U. Fever therapy revisited. Br J Cancer. 2005; 92:421-425.

6. Kuhl NM, Rensing L. Heat shock effects on cell cycle progression. Cell Mol Life Sci. 2000; 57:450-463.

7. Hirano H, Tabuchi Y, Kondo T, Zhao QL, Ogawa R, Cui ZG, Feril LB Jr, Kanayama S. Analysis of gene expression in apoptosis of human lymphoma U937 cells induced by heat shock and the effects of alpha-phenyl N-tertbutylnitrone (PBN) and its derivatives. Apoptosis. 2005; 10:331-340.

8. Trieb K, Blahovec H, Kubista B. Effects of hyperthermia on heat shock protein expression, alkaline phosphatase activity and proliferation in human osteosarcoma cells. Cell Biochem Func. 2007; 25:669-672.

9. Lindquist S. The heat-shock response. Annu Rev Biochem. 1986; 55:1151-1191.

10. DuBose DA, Balcius J, Morehouse D. Heat stress and/or endotoxin effects on cytokine expression by human whole blood. Shock. 2002; 17:217-221.

11. Moseley PL. Heat shock proteins and the inflammatory response. Ann N Y Acad Sci. 1998; 856:206-213.

12. Moseley PL. Exercise, stress, and the immune conversation. Exerc Sport Sci Rev. 2000; 28:128-132.

13. Guermonprez P, Valladeau J, Zitvogel L, Théry C, Amigorena S. Antigen presentation and T cell stimulation by dendritic cells. Annu Rev Immunol. 2002; 20:621-667.

14. Steinman RM. Some interfaces of dendritic cell biology. Apmis. 2003; 111:675-697.

15. Ardavin C, Amigorena S, Reis e Sousa C. Dendritic cells: immunobiology and cancer immunotherapy. Immunity. 2004; 20:17-23.

16. Banchereau J, Steinman RM. Dendritic cells and the control of immunity. Nature. 1998; 392:245-252. 
17. Foti M, Granucci F, Pelizzola M, Beretta O, RicciardiCastagnoli P. Dendritic cells in pathogen recognition and induction of immune responses: a functional genomics approach. J Leukoc Biol. 2006; 79:913-916.

18. Janeway CA Jr, Medzhitov R. Innate immune recognition. Annu Rev Immunol. 2002; 20:197-216.

19. Mortellaro A, Conforti-Andreoni C, Fric J, RicciardiCastagnoli P. Dendritic cells as sensors of environmental perturbations. Microbes Infect. 2008; 10:990-994.

20. Basu S, Srivastava PK. Fever-like temperature induces maturation of dendritic cells through induction of hsp90. Int Immunol. 2003; 15:1053-1061.

21. Knippertz I, Stein MF, Dörrie J, Schaft N, Müller I, Deinzer A, Steinkasserer A, Nettelbeck DM. Mild hyperthermia enhances human monocyte-derived dendritic cell functions and offers potential for applications in vaccination strategies. Int J Hyperthermia. 2011; 27: 591-603.

22. Lanzavecchia A, Sallusto F. The instructive role of dendritic cells on $\mathrm{T}$ cell responses: lineages, plasticity and kinetics. Curr Opin Immunol. 2001; 13: 291-298.

23. Sallusto F, Lanzavecchia A. Efficient presentation of soluble antigen by cultured human dendritic cells is maintained by granulocyte/macrophage colony-stimulating factor plus interleukin 4 and downregulated by tumor necrosis factor alpha. J Exp Med. 1994; 179:1109-1118.

24. Castiello L, Sabatino M, Jin P, Clayberger C, Marincola FM, Krensky AM, Stroncek DF. Monocyte-derived DC maturation strategies and related pathways: a transcriptional view. Cancer Immunol Immunother. 2011; 60:457-466.

25. Schuler G. Dendritic cells in cancer immunotherapy. Eur J Immunol. 2010; 40:2123-2130.

26. Lindholm P, Peränen J, Andressoo JO, Kalkkinen N, Kokaia Z, Lindvall O, Timmusk T, Saarma M. MANF is widely expressed in mammalian tissues and differently regulated after ischemic and epileptic insults in rodent brain. Mol Cell Neurosci. 2008; 39:356-371.

27. Apostolou A, Shen Y, Liang Y, Luo J, Fang S. Armet, a UPR-upregulated protein, inhibits cell proliferation and ER stress-induced cell death. Exp Cell Res. 2008; 314:24542467.

28. Castellino FJ, Ploplis VA. Structure and function of the plasminogen/plasmin system. Thromb Haemost. 2005; 93:647-654.

29. Bach LA, Fu P, Yang Z. Insulin-like growth factor-binding protein-6 and cancer. Clin Sci (Lond). 2013; 124:215-229.

30. Fu P, Liang GJ, Khot SS, Phan R, Bach LA. Cross-talk between MAP kinase pathways is involved in IGFindependent, IGFBP-6-induced Rh30 rhabdomyosarcoma cell migration. J Cell Physiol. 2010; 224:636-643.

31. Fu P, Yang Z, Bach LA. Insulin-like growth factor binding protein-6 (IGFBP-6)-induced rhabdomyosarcoma cell migration is modulated by binding to prohibitin-2. J Biol Chem. 2013; 288:29890-29900.

32. Babu PV, Si H, Fu Z, Zhen W, Liu D. Genistein prevents hyperglycemia-induced monocyte adhesion to human aortic endothelial cells through preservation of the cAMP signaling pathway and ameliorates vascular inflammation in obese diabetic mice. J Nutr. 2012; 142:724-730.

33. Landriscina M, Altamura SA, Roca L, Gigante M, Piscazzi A, Cavalcanti E, Costantino E, Barone C, Cignarelli M, Gesualdo L, Ranieri E. Reverse transcriptase inhibitors induce cell differentiation and enhance the immunogenic phenotype in human renal clear-cell carcinoma. Int $\mathrm{J}$ Cancer. 2008; 122:2842-2850.

34. Creery D, Weiss W, Lim WT, Aziz Z, Angel JB, Kumar A. Down-regulation of CXCR-4 and CCR-5 expression by interferon-gamma is associated with inhibition of chemotaxis and human immunodeficiency virus (HIV) replication but not HIV entry into human monocytes. Clin Exp Immunol. 2004; 137:156-165.

35. Shahabi NA, McAllen K, Sharp BM. Stromal cell-derived factor 1-alpha (SDF)-induced human $\mathrm{T}$ cell chemotaxis becomes phosphoinositide 3-kinase (PI3K)-independent: role of PKC-theta. J Leukoc Biol. 2008; 83:663-671.

36. McLeod SJ, Li AH, Lee RL, Burgess AE, Gold MR. The Rap GTPases regulate B cell migration toward the chemokine stromal cell-derived factor-1 (CXCL12): potential role for Rap2 in promoting B cell migration. $\mathrm{J}$ Immunol. 2002; 169:1365-1371.

37. Tournier JN, Hellmann AQ, Lesca G, Jouan A, Drouet E, Mathieu J. Fever-like thermal conditions regulate the activation of maturing dendritic cells. J Leukoc Biol. 2003; 73:493-501.

38. Macagno A, Napolitani G, Lanzavecchia A, Sallusto F. Duration, combination and timing: the signal integration model of dendritic cell activation. Trends Immunol. 2007; 28:227-233.

39. Li DY, Gu C, Min J, Chu ZH, Ou QJ. Maturation induction of human peripheral blood mononuclear cell-derived dendritic cells. Exp Ther Med. 2012; 4:131-134.

40. Boltjes A, van Wijk F. Human dendritic cell functional specialization in steady-state and inflammation. Front Immun. 2014; 5:131.

41. Tsan MF, Gao B. Heat shock proteins and immune system. J Leukoc Biol. 2009; 85:905-910.

42. Udono H, Ichiyanagi T, Mizukami S, Imai T. Heat shock proteins in antigen trafficking - Implications on antigen presentation to T cells. Int J Hyperthermia. 2009; 25:617625.

43. Bendz H, Ruhland SC, Pandya MJ, Hainzl O, Riegelsberger S, Braüchle C, Mayer MP, Buchner J, Issels RD, Noessner E. Human heat shock protein 70 enhances tumor antigen presentation through complex formation and intracellular antigen delivery without innate immune signaling. J Biol Chem. 2007; 282:31688-31702.

44. Kurotaki T, Tamura Y, Ueda G, Oura J, Kutomi G, Hirohashi Y, Sahara H, Torigoe T, Hiratsuka H, Sunakawa H, Hirata K, Sato N. Efficient cross-presentation by heat 
shock protein 90-peptide complex-loaded dendritic cells via an endosomal pathway. J Immunol. 2007; 179:1803-1813.

45. Shen L, Rock KL. Cellular protein is the source of crosspriming antigen in vivo. Proc Natl Acad Sci U S A. 2004; 101:3035-3040.

46. Martin CA, Kurkowski DL, Valentino AM, SantiagoSchwarz F. Increased intracellular, cell surface, and secreted inducible heat shock protein 70 responses are triggered during the monocyte to dendritic cell (DC) transition by cytokines independently of heat stress and infection and may positively regulate DC growth. J Immunol. 2009; 183:388-399.

47. Gallo PM, Gallucci S. The dendritic cell response to classic, emerging, and homeostatic danger signals. Implications for autoimmunity. Front Immunol. 2013; 4:138.

48. Raykha C, Crawford J, Gan BS, Fu P, Bach LA, O'Gorman DB. IGF-II and IGFBP-6 regulate cellular contractility and proliferation in Dupuytren's disease. Biochim Biophys Acta. 2013; 1832:1511-1519.
49. Lu S, Purohit S, Sharma A, Zhi W, He M, Wang Y, Li CJ, She JX. Serum insulin-like growth factor binding protein 6 (IGFBP6) is increased in patients with type 1 diabetes and its complications. Int J Clin Exp Med. 2012; 5:229-337.

50. Zhang $\mathrm{C}$, Lu L, Li Y, Wang X, Zhou J, Liu Y, Fu P, Gallicchio MA, Bach LA, Duan C. IGF binding protein-6 expression in vascular endothelial cells is induced by hypoxia and plays a negative role in tumor angiogenesis. Int J Cancer. 2012; 130:2003-2012.

51. Irizarry RA, Bolstad BM, Collin F, Cope LM, Hobbs B, Speed TP. Summaries of Affymetrix GeneChip probe level data. Nucleic Acid Res. 2003; 31:e15.

52. Fisher RA. On the interpretation of $\chi 2$ from contingency tables, and the calculation of P. Journal of the Royal Statistical Society. 1922; 85:87-94.

53. Reiner A, Yekutieli D, Benjamini Y. Identifying differentially expressed genes using false discovery rate controlling procedures. Bioinformatics. 2003; 19:368-375. 